\title{
Analysis of the Concept of Self Between Brahmanism and Buddhism
}

\author{
Rui $\mathrm{Xu}^{1, *}$ \\ ${ }^{1}$ Fuzhou University of International Studies and Trade, Fuzhou, Fujian, China \\ *Corresponding author. Email: 635524937@qq.com
}

\begin{abstract}
Discussions which relate to "Self" frequently appear in ancient Indian religious philosophies. The author found that both Brahmanism and Buddhism regarded the topic as greatly significant. It is notable however that the opinions which these faiths express in relation to this subject are different. Therefore, it is necessary to identify and assess the particular differences and similarities of their opinions for the sake of further exploration. The research will be of positive significance for creating an understanding of the developmental growth of Indian philosophy.
\end{abstract}

Keywords: Brahmanism, Buddhism, "Self"

\section{INTRODUCTION}

India is one of the four ancient civilizations in the world and its ancient civilization has exerted significant and far-reaching influence on the world. In particular, India's ancient religious philosophy is rich and profound, which plays a critical role in the history of the world's ideology. This cultural system has proposed a large number of concepts, categories or theories, among which Brahmanism and Buddhism are the two most prominent, important and representative ideological and cultural systems but what is on earth the relationship between these two contemplative systems of Buddhism and Brahmanism? What are their similarities and differences in thought? How do the two compete with and influence each other? The researches for these issues are abundant. For further exploration and research, the author thinks it is necessary to identify and evaluate the special differences and similarities of their viewpoints. With a strong focus on the definition for "self" of the two religions, this paper discusses the differences between the two viewpoints and has three parts. Part 1 discusses the Brahmanism interpretation of "I"; Part 2 expounds the Buddhism interpretation of "I", and Part 3 is the conclusion that reveals the reasons behind the differences through comparison.

\section{BRAHMANISM'S DEFINITION OF "SELF"}

When it comes to Brahmanism's notion and definition of "Self", it is inevitable that Veda and Upanishad will be cited. Both of these texts are regarded as being the oldest historical written works in India. There are fewer opinions regarding "Self" in the former. However some thoughts are closely linked with and have a significance influence on the understanding of later generations in relation to "Self". While the description and discussion of this topic encompasses a considerable part of Upanishad, it can be understood that the philosophical core of Upanishad focuses on "Self" to some extent. It provides important thought accumulation for the form and development of Brahmanism's theory of "Atman".

\section{A. The interpretation of "Self" in Veda}

Religious anthems constitute a greater part of Veda. The notion of "Self " can date back to Purusa sukta in Rigveda. From Purusa sukta 2.1: "The Purusha is indeed All this (Creation) in essence. That which existed in the Past, and that which will exist in the Future." And 2.2: "Everything is woven by the Immortal essence of the Great Lord (Purusha)" Rig Veda (10.90). We can see that Purusa was regarded as a dominator of all things. Everything in the past or in the future in essence is taken as Purusha. Besides this, in light of 2.2 "by becoming Food of which (i.e. by getting consumed in Whose Immortal essence through surrender) one transcends the gross world (and becomes Immortal)." Rig Veda (10.90). A conclusion may therefore be reached. Purusha becomes immortal in the samsara of all things in the world. The Purusha is similar to the "atman" which appeared in Upanishad and is referred to by later Indian generations.

\section{B. The interpretation of "Self" in Upanishad}

In Upanishad, "Self" and discussions which relate to it appear frequently throughout the text. Therefore it takes up a significant proportion of this essay. This is due to the intention of exploring the notion of "Self" in Upanishad. For the book's authors, there is indeed an eternal atman in the world. This is the inner absolution in consciousness which is the same as the essence of 
Brahman in everyone. According to Upanishad and the famous allegation "Tat tvam asi" ("ou Art is") ( Andrej ULE*2016:82) it is desirable to express the idea in an abbreviated manner. "Ou" refers to the atman which exists within us, while "is" refers directly to the Brahman itself. Therefore, it may be said that "atman is Brahman". Later, some Vedantists, especially Sankara took this notion as a means of identifying both personal and universal consciousness. These factors reflect the pure initial condition of ego. Therefore, it is concludes ataman exists immortally and eternally.

However, in fact, the "Self" in Upanishad may be delineated as both Brahman and atman. The Brahman can be understood as the universe or the entire world. Chandogya Up 3.14.1 stated that: "the whole world is Buddhist". In Svetasvatare Up 3.7 it is said that there is "something higher in the world which is Buddhist". The atman refers to human organs (such as eyes, ears, nose, tongue and skin). Philosophers of Upanishad believe that atman can assume a role as the controller of human consciousness and emotions. It may also be the subject in samsara and invoke extrication. According to Brharanyaka Upanishad 3.4 and 3.5: "You cannot see the seer who sees. You cannot hear the hearer who hears. You cannot think of the thinker who thinks. You cannot perceive the perceiver who perceives objects. The universal nature is yours too." Among the complicated relationships which occur between "Brahman" and "atman", what dominates Upanishad is the "moksha". This may be defined in the statement that: "the Buddhist and Intriguing into one". In Upanishad there are numerous philosophers who believed that the universe (Brahman) and human (atman) are consistent in essence. Brihadaranyaka Upanishad 3,7,15 says: "it exists in everything, nothing can understand it, and its body is all existence. It can control all existence from inside, it is your ego." There is another citation: (1953: 228) "Brahman is the only truth, the world is unreal, and there is ultimately no difference between Brahman and Atman, individual self." (Quote by Shankara from Vivekachudamani). Besides, in light of the description posited by Christopher Bartley, there is a further significant opinion which must be considered. The key to the meaning of life and the ultimate blessing exists in being able to comprehend the notion that the basic, inherent nature of humanity and the most central inner principal are same (Christopher Bartley, 2015: 34). Moksha can be also interpreted as a concept whereby all things are unified within Buddhism except for the abovementioned meaning. In addition, philosophers of Upanishad believed that the behavior of human beings can generate karma which results in metempsychosis. People in karma will feel the pain of right and wrong. Their abilities are not equal in relation to their ambitions. How may an individual rid themselves of this pain? When people decline the indulgence in meaningless pursuits, it becomes apparent that there is no karma without action. Negating the samsara will result in extrication. Therefore, the key of resolving problems exists in refusing to generate meaningless behaviors. When people understand that "all things are Buddhist" and anything independent from "Buddhist" does not exist, they will fail to conduct any meaningless actions. Isaupanishad Up 7: "people who understand everything are atman and see the ones who are free from confusion and pain."

We can say the theories regarding "Self" in Upanishad and Veda have established up the core concepts of the philosophy of Brahmanism. These thoughts brought an important influence on the emergence of Brahmanism. Vedanta, one of the sixschool philosophies of Brahmanism, directly followed and developed the theory regarding "Self" in Upanishad. Regarding the relationship between "Brahman" and "atman", are they entirely unified and indistinguishable? Are they essentially the same or almost the same? Different schools of Vedanta have different answers. What is the relationship between Buddhist and atman? Are they totally same, basically the same, or almost the same? Different answers to the relationship between the Buddhist and atman result in different branches of Vedanta. However, when Buddhism was established, Brahmanism's notion of "Self" was regarded as being a particularly negative standpoint. From this an ideological system which was exclusive from Brahmanism was established. However, the influence of Brahmanism, especially of Upanishad, remains apparent in certain aspects of Buddhist thought.

\section{BUDDHISM'S DEFINITION OF "SELF"}

Brahmanism has been in existence for a longer period of time compared with Buddhism. It is obvious the establishment of Buddhism partially drew on the concepts of Brahmanism, especially those aspects related in Upanishad. However, as a relatively new religion, the theory of Buddhism is naturally perceptively different from Brahmanism. It is notable that during the early developmental stages of the faith, its adherents understood this to be the case. However, they generally declined to accept the fact. The different ideas regarding the question of "Self" highlight the fundamental points of departure between Buddhism and Brahmanism. As Andrej asserted, for Buddhists, there is no 'atman' and no eternal ego which can accompany or exist in an individual consciousness's rebirth process. It can be said that the highest truth of Buddhism has already exceeded the differences between ego and nonego, existence and non-existence, condition and noncondition. Therefore, Buddhists deny the notion of absolute ego.

This bears a degree of similarity to the Brahmanist approach. At the very beginning, Buddhism taught that 
things result from the overlaying of nidana and that nothing is absolute. There is no "atman" in the life form of the human, and there is no single substantial thingin-itself of everything.

It has been stated that "The early Buddhists denied that (Anatta: No substance; no soul; no self that really matters.) There is anything essential to one's life if everything is always changing there are no fixed identities or natures. It is natural fact that a life is a series of phases of mental and physical events." Written by Christopher Bartley, a series of fundamental Buddhist thoughts have embodied the idea of "anatman". For example, the twelve-linked causal formulas, as the basic form of Prelude, are not unchangeable at all. The purpose of pañca skandha is also to negate an unchanged subject, emphasising that humans and their main functions are gathered by five elements and that nothing can dominate all things. Although Asamskrta will never increase or decrease and it will always exist, it differs from the concept of "atman". However, it is interesting to note that when Buddhism was established it upheld the notion of "anatman" and thereby defied the principal concepts of Brahmanism. However, the thoughts propagated in the earlier stages of Brahmanism were not entirely denied. A number of Brahmanist concepts which appeared in Upanishad were also deemed worthy of being drawn upon and integrated into the belief system of Buddhism. For example, it is apparent that samsara and moksa both correspond to Buddhist practices. When it comes to samsara and moksa, an inevitable need will arise to answer the following questions. Who created karma which entered into samsara and moksa? Who achieved ultimate moksa due to padipata of a certain extent? However, both samsara and moksa are linked to a quandary. This is the need for a subject to assume responsibility for their actions. There is also the subject of "atman" in Brahmanism, so it explains that samara and moksa are very easy. The relationship between the theory of ataman, samsara and moksa are particularly clear. It is comparatively easy to achieve maksa. However Buddhism's explanation regarding this is particularly complicated. This was not apparent in the early stages of Buddhism, and during the period of Sectarian Buddhism, the inner faction of Buddhism became aware of the problem. Therefore schools of Sectarian Buddhism began to employ other forms of "atman".

\section{THE COMPARISON BETWEEN BUDDHISM AND BRAHMANISM}

It is apparent from the previous discussions that the essential aspects of Buddhism and Brahmanism differ in a number of fundamental ways. Generally, the latter emphasises atman while the former promotes the belief in anatman. The essential differences between atman and anatman are very clear, although their perceptions regarding "atman" have changed throughout the development of history. The alternative branches of belief insist on an adherence to different standpoints. It is linked to basic standpoints on the essence of things in the world and directly to the interests of the different social classes which they represent. The standpoints on the essence of things in the world serve to entirely differentiate the two religions from each other. The main ideology of Brahmanism is single factor theory, whilst Buddhists believe that there is a fundamental factor among all things in the world or the phenomena of life which is eternal or unchangeable in essence. The "atman" represents this kind of fundamental factor. For example, there exists the Brahman in every phenomenon. In the world, there is an atman in every person and emotion. This kind of "atman" is the fundamental factor. Everything in the world or life phenomenon centers on the fundamental factor and regards it as reality.

However, Buddhism upholds the origin theory, positing the belief that there is no fundamental factor which relates to everything in the world and the life phenomenon. If there are origins, they are comprised of origins which are dependent on each other for existence or origins that are mutually conditional. These can be regarded as origins and also as karma. Its form is not unchangeable and eternal or immortal. Thus, the schools of Brahmanism all agree that there are unchangeable subjects, although some of these uphold the theory that Brahman and atman are the one and for some of them atman only exists in life phenomenon. Nevertheless, for Buddhism, both branches completely uphold the theory of anatman and the branch which upholds the theory of atman. However, they do not acknowledge the fact that there are really any truly unchangeable subjects in essence. Although certain subjects are described as real and unchangeable in certain Buddhist texts, these are only convenient but inexact explanations.

Their different interpretations of "atman" are the results of social and historical factors. The founder of Brahmanism principally occupies the class of 'Brahman' which represents its own political or economic interests. Since ancient times, an influential social system has operated in throughout India. This is referred to as the caste system. According to a set of established rules, each caste has its own social obligations and rights. The distinctions and limitations which distinguish these classes are absolute and individuals of different denominations are denied the right to intermix. The upper classes are especially privileged and are granted the right to rule over those of lower castes. Individuals who belong to lower castes are required to obey the commands of the upper ones. 
An individual's caste is hereditary, decided by his or her status from birth onwards Brahmanism has a political perspective and one of its most fundamental rules is known as "Brahman the superior" (Taittiriya Upanisad 2.1.1) "He who knows the Brahman attains the highest. The Brahman is reality, conscious and infinite." They believe that those who inhabit the caste of Brahman will always enjoy an elevated position within Indian society. Such individuals are regarded as representing the core of the nation's society. The status is ingrained and will last forever. For example, George C. Adams (1993:75) wrote that: " the person in the eye was earlier described (Chandogya Upanisad 4:10:4) as qualified by pleasure $(\mathrm{Ka})$ and since the being qualified by pleasure is declared to be the Brahaman, the person in the eye must be the Brahman, too." Under such circumstances, the philosophy of Brahmanism insists that there are unchangeable and eternal subjects "this person that appears in the eye, that is immortal, that is free from fear, that is the Brahman." (Chandogya Upanisad 8.7.1ff). "Atman" is regarded as the subject. It truly exists and is immortal which is consistent with the political view that "Brahman is the superior" as well as the standpoint that the central positioning of the upper castes is infinite. Albrecht Weber, a distinguished German-Indian asserted that: " the origin is one of the most splendid and radical reactions against the common human rights, opposing oppressive tyranny, hypocritical holy origin, unequal birth and the privilege of class." They are dissatisfied with the strictly enforced caste system which is reflected in Buddhist literature. One of the most renowned statements which Buddha expressed is as follows: "Birth does not make one a priest or an outcast. Behaviour makes one either a priest or an outcast."(Malalasekera, G.P. 1968). A person's social status should not be dictated by their status at birth but by their personal actions or sense of morality. People from low classes are also likely to be person of virtue.

In fact, Buddhism upholds the equity of the four castes which is further defined in the statement that "all men are created equal". This has evolved into an influential political slogan for Buddhism. In light of the political standpoint, the social status may be altered; no particular caste will always occupy the core status. Therefore, naturally, Buddhism upholds non-subject theory or the theory of change The Buddhist view is that intrinsically self-aware, subject-less thoughts are thinking themselves, as well as each other. They do not need illumination by consciousness belonging to a persisting subject (Christopher Bartley, 2015: 35). It is natural to uphold the theory of anatman when analysing notions or phenomenon which occur throughout life. Only in this way the faith be coordinated with its political standpoints and expand its influence among the public.

\section{CONCLUSION}

The different standpoints of "Self" which are apparent between Buddhism and Brahmanism mirror their fundamental theoretical differences as well as the political conflicts which exist throughout the different classes in ancient India. Both of these religions possess a profound ideological system. generally speaking, the former insists on the theory of Atman while the latter emphasizes. the theory of Anatman. Of course, during its developmental process, Buddhism also upheld the theory of Atman. However a number of differences are apparent in Buddhism's interpretation of "atman". These are identifiable over the course of a number of different phases. Different schools of Brahmanism also expressed their alternative ideas regarding the subject. It is notable and significant that a number of their specific concepts are focused on the defining notion of "Self".

\section{References}

[1] ULE, Andrej. (2016). The Concept of Self in Buddhism and Brahmanism: Some Remarks. Asian Studies, 4(1), p.81.

[2] Brharanyaka Upanishad 3.4 and 3.53 .4 and 3.5

[3] Brihadaranyaka Upanishad 3.7.15

[4] Chandogya Upanishad 3.14.1; Chandogya Upanisad 4.10.4; Chandogya Upanisad 8.7.1ff

[5] Christopher Bartley, An Introduction to INDIAN PHILOSOPHY Hindu and Buddhist Ideas from Original Sources, 2015, Bloomsbury Academic An imprint of Bloomsbury Publishing Plc.

[6] George C. Adams, The Structure and Meaning of Bādarāyaṇa's Brahma Sūtras: A Translation and Analysis of Adhyaya 1

[7] Isaupanishad Upanishad 7

[8] Malalasekera, G.P. and Jayatilleke, K.N. Buddhism and the Race Question UNESCO, 1968

[9] 12,2015 (The Complete Beginners Guide To The Upanishads)

[10] On Weber and his work see E. Windisch, Geschichte der Sanskrit-Philologie und indischen Alter- tumskunde, Strassburg, 1917, pp. 319-355 and 361-364 and passim;)

[11] Purusa sukta in Rigveda Rig Veda (10.90). (2.1,2.2)

[12] Svetasvatare Upanishad3.7

[13] Taittiriya Upanisad 2.1.1 